\author{
Tomasz M. NAPIÓRKOWSKI, PhD \\ Instytute of International Economics, Warsaw School of Economics \\ e-mail: tnapio@sgh.waw.pl
}

DOI: $10.15290 /$ ose.2017.05.89.16

\title{
THE ROLE OF FOREIGN DIRECT INVESTMENT IN ECONOMIC GROWTH. THE PRODUCTION FUNCTION PERSPECTIVE ${ }^{1}$
}

\begin{abstract}
Summary
Throughout the studies on the impact of foreign direct investment (FDI) on the economic growth of the host economy, there is a significant heterogeneity in terms of the results; not only between the theory and empirics, but also within empirics itself. The aim of this study is to explain the heterogeneity of results of the previous studies on the benefits of hosting FDI. This work uses the topic-relevant literature to present the key benefits of inward FDI, which are then translated into a mathematical model, which the direct and indirect benefits are derived from and differentiated between. Firstly, this work develops a production function including the key direct and indirect effects of hosting FDI in order to (through the proof of endogenization of FDI) show that a simple inclusion of FDI as the next (usually along with capital and labor) factor of growth may lead to spurious and, therefore, inconsistent results. Secondly, the study introduces the Foreign Direct Investment Benefits Absorption Path, which due to its classification of host economies into four distinctive groups, differentiating between direct and indirect benefits of FDI, and showing their different ways of impacting the host's economy provides a unique insight into the topic of heterogeneity of results on the impact of hosting FDI. It also provides a blueprint for further research into this topic. Lastly, the Foreign Direct Investment Benefits Absorption Path is used to develop FDI-related strategies aimed at increasing the economic growth of host countries.
\end{abstract}

Key words: economic growth, foreign direct investment, absorption path

JEL Classification: O33, O34, F21, F43

\section{Introduction}

Foreign direct investment (FDI) and its impact on the host economy has been the topic of many works. The problem is that, in many instances, there is a certain degree of discrepancy between theoretical and empirical studies [Nair-Reichert, Weinhold, 2001; McGrattan, 2011; Iamsiraroj, Ulubaşoğ, 2016]. Therefore, the aim that this study intends to achieve is to explain why various studies on the benefits of hosting FDI achieve different, sometimes opposite, results, which can also differ from those suggested by the theory

1 This publication is a result of statutory research of the Collegium of the World Economy at the Warsaw School of Economics, financed with funds from Ministerstwo Nauki i Szkolnictwa Wyższego. 
of economics. The question then is: Can these discrepancies have a theoretical origin? Therefore, the resulting research question is: What are the possible sources of the discrepancy between the obtained results? The first hypothesis (H1) is that these differences result from too exogenous treatment of FDI. ${ }^{2}$ The second hypothesis $(\mathrm{H} 2)$ is that the level of heterogeneity of host economies along the absorption capability spectrum and the heterogeneity of foreign direct investment benefits themselves along the same path can be a significant source of contradicting results.

The void in literature that this study aims to fill is the problem of presenting how the impact of benefits of FDI varies depending on their host's absorptive capacity and how these differences (in addition to embeddedness of FDI and separation of direct and indirect ones) can lead to the heterogeneity of results connected with this topic.

To test the set hypotheses, firstly, a literature study is employed to present key direct and indirect benefits of hosting FDI. Secondly, as regards the transformation of the initial two-factor growth function, the degree to which the inward FDI activity is intertwined with the growth of the host economy (in reference to H1) is shown. Thirdly, as regards the distinction between the direct and indirect effects of FDI, it is shown which of the two play the chief role in stimulating the host's economy as it develops along the absorption path (H2).

This research will introduce the concept of the FDI Benefits Absorption Path (FBAP).

\section{Literature review - effects of FDI on the host economy}

The aim of this section is to present a literature background for the further-studied effects (both, direct and indirect) of hosting $\mathrm{FDI}^{3}$ and the topic of the host's absorptive capacity.

The first examined relationship is that of incoming FDI and the domestic level of investment. Pilbeam and Oboleviciute in their 2012 study of new and old European Union members found that there is no negative impact of FDI on the level of domestic investment in the prior countries, but there is in the latter. This study, therefore, shows that the conclusions in the discussion on crowding in or out of domestic investment by FDI is country-dependent (later it will be shown, however, that this is not necessarily the case). Furthermore, considering that the old EU consists of more developed economies then the new EU, it can by hypothesized that there is a direct relationship between the level of the economic development of the host and the significance of the discussed crowding out effect. Ahmed et al. [2015], when studying Uganda, go even further, as they

2 Because the topic itself is not new, there is a multitude of studies that apply various approaches. The most common one is the use of FDI as a determinant of growth along with other topic-specific independent variables and a set of control variables [e.g., Carkovic, Levine, 2002; Alfaro, 2003; Zghidi et al., 2016; Iamsiraroj, 2016]. The issue is that, in such an approach, FDI is treated too exogenously given its deep penetration of host's economy.

3 Obviously, it is impossible to focus on all the possible effects of FDI for the host economy; therefore, it was decided to focus on the chief ones. 
have shown that whether FDI crowds in, crowds out or is neutral in reference to domestic investment is sector-dependent. Interestingly, the authors have stated there is an overall neutral effect for the economy of Uganda as a whole. What is even more interesting is the heterogeneity of obtained results when studying the same economies. As mentioned earlier, Pilbeam and Oboleviciute [2012, p. 89] have found that "FDI has no negative impact on domestic investment in the new EU member states" (Bulgaria, Cyprus, Czech Republic, Estonia, Hungary, Latvia, Lithuania, Malta, Poland, Romania, Slovenia and Slovakia) while Szkorupová [2015, p. 1021], when studying Czech Republic, Estonia, Hungary and Slovakia, concludes that the "[n] egative crowding out effect of domestic investment by foreign direct investment was proved"; hence, abolishing the earlier-mentioned hypothesis of results being country-dependent. Such divergence among the results have not been unnoticed by other researchers. And so, Farla et al. [2016] claim that opposing conclusions may be the results of inappropriate proxies used by the researchers for theoretical concepts. The results are also shown to be research method dependent. To prove that through "[i]mprovements in the construction of the proxies and refinements in the estimation methodology" [Faral et al., 2016, p. 1], they have shown opposite results to those obtained by Morrissey and Udomkerdmonkol [2012], who have concluded that FDI inflows do crowd out domestic investment. Despite conflicting evidence, which can be a derivative of (in addition to the two reasons mentioned above) poor quality of data [Morrissey, Udomkerdmonkol, 2016], an assumption was made, that the overall impact of inward FDI on the level of investment is not positive.

The fact that foreign firms tend to pay higher wages to the host's employees has been confirmed by Tomohara and Takii [2011]. Higher wages are offered chiefly for the following reasons: 1) the home country regulations or home-country pressures, 2) workers have a preference of domestic firms and must be compensated to ignore their preferences, 3) higher wages are treated as a premium to reduce worker turnover and 4) foreign investors lack the knowledge of the local labor market, which does not allow them to individually identify and employ the best workers without offering them higher pay [e.g. see Lipsey, 2002; Javorcik, 2015]. Very interestingly, Heyman et al. [2007, p. 370] find that although foreign firms do pay higher wages than domestic firms, "there is no evidence that foreign firms pay higher wages for identical workers. Instead, higher wages in foreign-owned firms are caused by differences in firm and worker characteristics ... [further] ... the results suggest that the difference between multinational and nonmultinational firms, rather than between domestic- and foreign-owned firms, is important”. Regardless of the findings of Heyman et al. [2007], the fact remains that the presence of FDI does tend to increase the overall average wage in the host economy ${ }^{4}$.

Transfers of technology is the first of the two key spillovers which are included in this study. Blomström and Sjöholm [1999, p. 923], while recognizing the existence of technology spillovers, come to a conclusion that they "are more a result of the increased competition that follows FDI than ownership sharing of the multinational affiliates".

4 For more on the adjustment pattern of regional wages due to inward FDI (specifically in Central and Eastern European economies) see Damijan and Kostevc [2011]. 
When studying the Chinese electronic industry, Liu et al. [2016] find that foreign capital is the primary channel through which technology is delivered to domestic firms in the studied industry. The positive impact of new technology that comes with foreign investors has also been noticed by Svedin and Stage [2016], with a note that the impact of such transfers can be so significant that it can hide decreased resource efficiency, which in turn derives from such factors as a limited understanding of the domestic business environment. On the other hand, Munteanu [2016] notes that the benefit of technology introduced through FDI can be overshadowed by the negative impact on the competitiveness of local firms. Researchers like Fatima [2016] distinguish between horizontal and vertical technology spillovers, where the prior comes from intra- and the latter from inter-industry linkages between foreign and domestic enterprises. Furthermore, the author claims that FDI spillovers increase productivity only if they are of a vertical nature. As it can be seen, despite various authors approaching the topic of technology spillovers from various angles, one common thread (i.e., the starting point) is that, at least from the theoretical perspective, FDI technology spillovers do play a positive role in shaping of the host's GDP.

The researchers seem to have less divided opinions on the direction of changes when it comes to the second key spillover included in this study, that is transfer of knowledge, which is a corner stone of the domestic human capital. In their 2016 work on the importance of human capital to economic growth, Teixeira and Queirós [2016, p. 1637] describe it as "the set of intangible resources embedded in the labor factor which have improved its productivity". In their introductory discussion on the significance of FDI in the shaping of the host's economy, Tülüce and Doğan [2014, p. 110] highlight its role by simply saying that FDI is a "leading force of growth for every developing country" and that it brings with it not only additional capital, but also the earlier-discussed technology and the here-discussed know-how. Interestingly, the authors find that although FDI can impact such determinants of growth as the quality of the labor force, this may not be evident when looking at productivity measures. The transfer of know-how is also listed as one of the key FDI-associated benefits by Temiz and Gökmen [2014, p. 153], which the authors say cannot be achieved with an "old-dated application" as they find no significant relationship between inward FDI flows into Turkey and its economic growth. Wang and Wu [2016] show that the significance of the knowledge spillovers can depend on whether they are inter- (positive and significant) or intra-sector and that the size of knowledge spillovers is impacted by the level of innovation of domestic firms. Branstetter [2006], when studying the flow of knowledge as a results of FDI (on a Japan-USA case), found evidence of FDI-stimulated knowledge spillovers in both directions, from and to the investing enterprise. Lastly, it is important to note that the role of knowledge spillovers is to increase the value (the benefit) of technology spillovers [Munteanu, 2016]. As a result, knowledge/know-how spillovers resulting from FDI are found to be significant for the economic growth of the host and, therefore, are included in this study.

The general thought in literature on the magnitude of the effects of FDI spillovers on the host economy is that "the capability of local firms to absorb superior technol- 
ogy and knowledge appears to be a decisive determinant of whether or not the potential for spillovers will be realized" [Nunnenkamp, 2002, p. 32 - also see: Borensztein et al., 1998; Velde, 2006; Azam, Ahmed, 2015]. This absorptive capacity is determined by such factors as domestic investments in the development of local human capital (in addition to some of the just-cited works, e.g. see: [Blomström, Kokko, 2003]. Another significant absorptive capacity variables are financial development and trade-openness [Iamsiraroj. Ulubaşoğlu, 2015]. Another important thread in the discussion on the absorptive capacity of the host is the notion of a 'gap' between the host and the home economy. In their study, Tomohara and Takii [2011, p. 518] note that there exists a thread in literature that examines the relationship between the technology gap between the host and the home economies and the existence/size of technology spillovers; however, the authors note that the obtained results are 'controversial' - a notion also highlighted by Liu et al. [2016], who found that the bigger the productivity gap, the more constrained the impact of FDI. Very interestingly, in their literature review, Tülüce and Doğan [2014] show that opposite conclusions can be reached by the same researcher. The idea that the ability to absorb technology spillovers is indirectly related to the technological gap between the host and the home economies has been noted by Blomström and Sjöholm [1999]. The importance of the technology gap as a determinant of the value of the spillovers have also been highlighted by Munteanu [2016]. On the other hand, Fatima [2016] found no support for the premise that the capacity of host firms to benefit from backward or forward linkages is dependent on the technology gap.

This section showed that despite some heterogeneity in the results, (1) the further studied effects (direct: new investment and higher average wages; indirect: transfer of technology and of know-how/knowledge) are expected to impact the economic growth of the host economy in a positive manner and (2) the extent of these effects in terms of spillovers is dependent on the absorptive capacity of the host. These findings serve as the starting point for the following discussion.

\section{Theoretical perspective of the role of inward FDI in economic growth}

The goal of this part of the article is to present the degree to which inward FDI is embedded in the economic growth of the host economy and to indicate it as one of the sources of divergence among various studies on this topic.

The analysis starts with the basic growth function [Solow, 1956] where the output of a closed economy (i.e. one defined in this study as possibly conducting international trade transactions, but without inward FDI activity, $Y$ ) is a function of the level of the capital $(K)$ and the available amount of workers represented by units of the labor force $(L)^{5}$; all states are given per period $t($ Equation 1$)$.

5 The reason why this model incorporates labor force and not population is to account for the amount of units available for production; e.g. a new-born increases the size of population, but not the current level of the labor resources 


$$
Y_{t}=f\left(K_{t}, L_{t}\right)
$$

Source: Solow [1956].

Based on such works as Romer (1990) and Aghion and Howitt (1992), the initial function is corrected by the level of existing technology $(A)$ and human capital $(H)$ (Equation 2) ${ }^{6}$.

$$
Y_{t}=A_{t} f\left(K_{t}, L_{t}, H_{t}\right)
$$

Source: Author's own elaboration based on [Romer, 1990; Aghion, Howitt, 1992].

In order to incorporate the 'golden rule' level of capital per unit of labor $\left(\mathrm{k}^{*}-\right.$ the optimum relationship of capital to labor), all variables (with the exception of the level of technology) are divided by Lt (yt $=\mathrm{Yt} / \mathrm{Lt} ; \mathrm{kt}=\mathrm{Kt} / \mathrm{Lt}$; $\mathrm{ht}=\mathrm{Ht} / \mathrm{Lt})$; giving the equation in per unit of labor force form (Equation 3).

$$
y_{t}=A_{t} f\left(k_{t}, h_{t}\right)
$$

Source: Author's own elaboration.

In order to include the (further-discussed) impact of FDI on the change in the level of host's technology, it is advantageous to include the growth rate of technology (g). Today's level of available technology $(\mathrm{At})$ is equal to the level from the previous period (At-1) adjusted to its growth rate $(1+\mathrm{g}$; Equation 4$)$; all subjecting the basic equation to further analysis.

$$
y_{t}=(1+g) A_{t-1} f\left(k_{t}, h_{t}\right)
$$

Source: Author's own elaboration.

What follows is the development of the established starting point due to the addition of first, direct and second, indirect benefits of FDI.

\subsection{Direct effects of inward FDI on economic growth}

The aim of this section is to consider the direct effects of hosting FDI, i.e. (1) the inflow of funds, (2) the increase in average wages and the resulting (3) capital formation.

Suppose that prior to inward FDI, the level of investment in the economy is determined (based on the principle of savings = investment) by the share of the income $\operatorname{saved}^{7}(s y$; Equation 5, where $s$ is the marginal propensity to save).

\footnotetext{
6 Because knowledge is represented within $H, A$ is said to augment all factors of production, i.e. technology is seen to increase the productivity of $K, L$ and the efficiency of application of $H$.

7 Just like in similar models, for simplicity reasons the marginal propensity to save is determined here exogenously to the discussed model.
} 


$$
i_{1}=s y_{1}
$$

Source: E.g., see Solow [1956].

When FDI is implemented in the host economy, its level of investment increases by iFDI, which yields the fact that (since iFDI >0) i2 > i1 (Equation 6).

$$
i_{2}=s y_{1}+i_{F D I}
$$

Source: Author's own elaboration.

Furthermore, given that income (y) is determined by the level of wages (w), as marginal to the system, wages paid by the foreign investor tend to be higher than the ones paid by domestic firms, the average wage in the host economy increases by the difference between the foreign and the domestic level of wages (wFDI - w1) (Equation 7).

$$
w_{2}=w_{1}+\left(w_{F D I}-w_{1}\right)
$$

Source: Author's own elaboration.

As a result, w2 $>\mathrm{w} 1$; hence, $\mathrm{y} 2>\mathrm{y} 1$ (where $\mathrm{y}$ is determined by a set of factors $\mathrm{N}$ and by w) (Equation 8).

$$
y_{2}=f\left(N, w_{2}\right)
$$

Source: Author's own elaboration.

As a result, the new level of investment (i3) is a function of the share of new income (y2) saved and the additional foreign investment (iFDI); where i3 > i2 (Equation 9).

$$
i_{3}=s f\left(N, w_{2}\right)+i_{F D I}
$$

Source: Author's own elaboration.

As a result of the increase in investment, the relative value of capital $\mathrm{k}$, which is the difference between the starting level of capital $(\mathrm{k} 0)$ with new investment and the change in $\mathrm{k}$ resulting from the growth in labor (n), the change in the level of technology $(\mathrm{g})$ and the depreciation of existing capital ( ) (Equation 10) increases, i.e. $\mathrm{k} 2>\mathrm{k} 1$; where $\mathrm{k} 2$ is the level of $\mathrm{k}$ that includes the impact of inward FDI on investment.

$$
k_{1}=k_{0}+i_{1}-(n+g+\delta) k
$$

Source: E.g., see [Solow, 1956].

The result is the new formula for $\mathrm{k}$ (Equation 11), which includes a new level of investment (Equation 9) and the new level of wages (Equation 7). 


$$
k_{2}=k_{0}+\left(s f\left(N, w_{2}\right)+i_{F D I}\right)-(n+g+\delta) k
$$

Source: Author's own elaboration.

At this point, it can be seen that the inflow of FDI increases the level of investment due to two factors, i.e. (1) increase in wages and (2) inflow of funds; where both lead to an increase in the level of capital per unit of labor force. Next, the examination of indirect benefits of FDI is conducted.

\subsection{Indirect effects of inward FDI on economic growth}

While the previous section looked at the more tangible (i.e., directly measureable) effects of inward FDI for the host, the aim of this part is to analyze the role of FDI spillovers (i.e., technology and knowledge transfers), which are less tangible and much harder to measure [Keller, 2009].

The first of the two key spillovers is the transfer of technology, which impacts the rate of change in the level of technology in the host economy - represented by its growth rate $g^{8}$. In the absence of inward FDI and its spillover of technology transfer, the domestic level of technology $\left(A_{1}\right)$ is growing at its natural rate that is stimulated only by domestic activity (including trade) $g_{1}$. Because technological advance is a positive change and it virtually cannot be undone, it is reasonable to state that $0 \leq g_{1} \leq 1$. This implies that $A_{1, t} \geq A_{1, t-1}$ (this relationship is described by Equation 12 ).

$$
A_{1, t}=\left(1+g_{1}\right) A_{1, t-1}
$$

Source: Author's own elaboration.

The impact of inward FDI on the level of technology is evident in an additional increase in $g$, here represented by $g_{F D I}$. Hence, the growth rate of technology in the host economy is determined by its domestic factors $(\Lambda$, Equation $13 \mathrm{a})$ and the just-mentioned transfer of technology ( $g_{F D I}$, Equation 13b).

$$
\begin{gathered}
g_{1}=f(\Lambda) \\
g_{2}=f\left(\Lambda, g_{F D I}\right)
\end{gathered}
$$

Source: Author's own elaboration.

Therefore, Equation 12 is transformed (with the use of Equation 13b) into Equation 14 to include the discussed spillover effect, where $A_{2, t}>A_{1, t}$.

$$
A_{2, t}=\left(1+g_{2}\right) A_{1, t-1}=\left(1+f\left(\Lambda, g_{F D I}\right)\right) A_{1, t-1}
$$

Source: Author's own elaboration.

8 Given that there is a clear distinction between time periods needed for the inclusion of $g$, a subscript $t$ (dropped for the earlier analysis) is brought back. 
The second key indirect benefit of FDI hosting is the transfer of knowledge/knowhow, which positively contributes to the level of human capital of the host economy (hi), which is determined by a set of domestic factors represented by $M$ (Equation 15).

$$
h_{1}=f(M)
$$

Source: Author's own elaboration.

Because this transfer of knowledge $\left(h_{F D I}\right)$ is positive, the human capital of the economy hosting inward FDI $\left(b_{2}\right)$ is higher than in the case of its absence $\left(b_{1}\right)$ and can be described by Equation 16.9

$$
h_{2}=f\left(M, h_{F D I}\right)
$$

Source: Author's own elaboration.

This part has developed the two-factor growth function basing on a collection of previous studies on the impact of FDI, the result of which is the establishment of FDI as a significant building block of the host economy.

The chief conclusion drawn from the previous section on empirical research on the impact of FDI on the host's economic growth is that (with an increasing degree of multinationalism of firms and economies) FDI has solidified its role as a determinant of economic growth of the domestic economy ${ }^{10}$. Therefore, the omission of FDI from economic growth equation may lead to spurious results. ${ }^{11}$ Hence, the initial growth model (Equation 4) can be transformed into Equation 17 and its fully extended version shown in Equation 18.

$$
y^{F D I}=\left(1+g_{2}\right) f A_{1, t-1} f\left(k_{2}, h_{2}\right)
$$

Source: Author's own elaboration.

$$
\begin{aligned}
y^{F D I}=[1+ & \left.f\left(\Lambda, g_{F D I}\right)\right] A_{1, t-1} f\left[k_{0}\right. \\
& \left.+\left(s f\left(N, w_{2}\right)+i_{F D I}\right)-\left(n+f\left(\Lambda, g_{F D I}\right)+\delta\right) k, f\left(M, h_{F D I}\right)\right]
\end{aligned}
$$

Source: Author's own elaboration.

Transformation of Equation 18 into its basic linear form (Equation 19) further shows that estimation of the basic growth function (with FDI simply as one of its factors) for the host economy is impossible without the consideration of the embeddedness

\footnotetext{
9 An additional benefit of a transfer of know-how is a direct and costless increase in $h$. It is costless in the sense that no units counted as a part of $L$ have to leave the system, e.g. to obtain more education.

10 These conclusions fall in line with the discussion of Dependent Market Economies presented by Nölke and Vliegenthart [2009].

11 This is especially true for such countries as Poland and other Central and Eastern European economies, where FDI continues to play a vital role [Kornecki, 2008; Kuskowski et al., 2010; Popescu, 2014].
} 
of FDI. The difficulty of this task increases simultaneously with the increasing role of indirect effects of inward FDI - this is due to the difficulty of their measurement ${ }^{12}$.

$$
\begin{aligned}
\ln \left(y_{t}^{F D I}\right)=[1 & \left.+f\left(\Lambda, g_{F D I}\right)\right] A_{1, t-1} \\
& +\beta_{1} \ln \left[\left(k_{0}+s f\left(N, w_{2}\right)+i_{F D I}\right)-\left(n+f\left(\Lambda, g_{F D I}\right)+\delta\right) k\right]_{t} \\
& +\beta_{2} \ln \left[f\left(M, h_{F D I}\right)\right]_{t}+\varepsilon_{t}
\end{aligned}
$$

Source: Author's own elaboration.

The correct estimation of parameters in Equation 19 is dependent on a couple of factors. Firstly, its estimation requires the inclusion of the determinants of $g(\Lambda)$ and $h(M)$ different than their FDI components. In order to avoid the problem of model overspecification, it would force the use of multiple parallel models, the results of which would serve as inputs into Equation $19 .{ }^{13}$ Secondly, there is the issue of the correct measurement of $g_{F D I}, w_{F D I}$ and $h_{F D I}$. While the measurement of $w_{F D I}$ (a part of a direct effect of hosting FDI) can be estimated based, e.g. on previous microeconomic studies [Heyman et al., 2007], the correct measurement of values of spillovers (indirect effects of hosting FDI), i.e. transfers of technology $\left(g_{\mathrm{FDI}}\right)$ and of know-how $\left(b_{\mathrm{FDI}}\right)$ is (as mentioned earlier in this text) significantly more troublesome ${ }^{14}$. Any issue of mismeasurement may lead to false parameter estimates ${ }^{15}$.

The obvious questions which follows concerns the size of the impact of FDI on the economic growth of the host. Taking under consideration previous derivations (Equation 19), the measure of the impact of FDI on the host economy is a function of $\frac{\partial y^{F D I}}{\partial g_{F D I}}, \frac{\partial y^{F D I}}{\partial w_{F D I}}, \frac{\partial y^{F D I}}{\partial i_{F D I}}$ and $\frac{\partial y^{F D I}}{\partial h_{F D I}}$, and their value (as will be shown in the next section) depends on the stage of the FDI Benefits Absorption Path, which the host occupies.

\section{Value of the impact of FDI on the host's economy}

In terms of the value of the impact of FDI, the most challenging problem is in the value of impact of indirect effects (i.e., transfer of knowledge/know-how and of technology). Such transfers can occur through two general channels: (1) directly through

12 Indirect effects, e.g. the impact of inward FDI on the development of human capital, can be estimated following, e.g. the procedure of Total Factor Productivity with the said impact taking the place of Solow's residuals. However, the validity of this procedure is highly-dependent on the assumption that all and only non-FDI factors are represented in the initial growth model by the used explanatory variables (i.e. model's residuals $=$ FDI).

13 An alternative solution could be found in the use of VAR models with impulse response and variance decomposition analysis, but this would require high-frequency data (long time-series). This requirement could be eliminated thanks to the use of a panel; however, this would require a significant degree of homogeneity across the subjects in order to avoid spurious results.

14 This is even truer when one realizes that for many economies a limited time-series set of FDI data forces a panel study, which itself forces a unified measurement of the said spillover effects across all crosssections.

15 Again, one possibility would be to apply the procedure similar to the one of Solow's Residuals, but this entails its own set of possible limitations [e.g. see Burda, Severgnini, 2014]. 
ownership and (2) indirectly through spillovers. They occur as a result of an introduction of new technology and new organizational skills by the home firm, which are at a higher level than those possessed by the host company [Damijan et al., 2013].

Given Equation 3 and the natural progression of input development (labor force followed by capital accumulation and human capital, and technology development), it is reasonable to assume that the economies with a low value of $y$ have low levels of both, $k$ and $h$. In other words, they have a low level of absorptive capacity. This leads to an observation, that the values of $\frac{\partial y^{F D I}}{\partial g_{F D I}}, \frac{\partial y^{F D I}}{\partial w_{F D I}}, \frac{\partial y^{F D I}}{\partial i_{F D I}}$ and $\frac{\partial y^{F D I}}{\partial h_{F D I}}$ are determined by the host's absorptive capacity and their size and relative strength change along the absorptive capacity spectrum.

Without the absorptive capacity, the impact of the direct benefits of inward FDI is the same as the increase in the savings rate, i.e. they simply cause an increase in $k$, which (given decreasing marginal returns of capital) does add to the value of output per unit of labor force, but with a decreasing efficiency and can lead to a decrease in consumption [Romer, 2001]. Hence, it cannot be considered to impact the growth rate of output per unit of labor force on the balanced growth path ${ }^{16}$ - however, a change in technology and human capital can.

FIGURE 1.

Four stages of the FDI Benefits Absorption Path

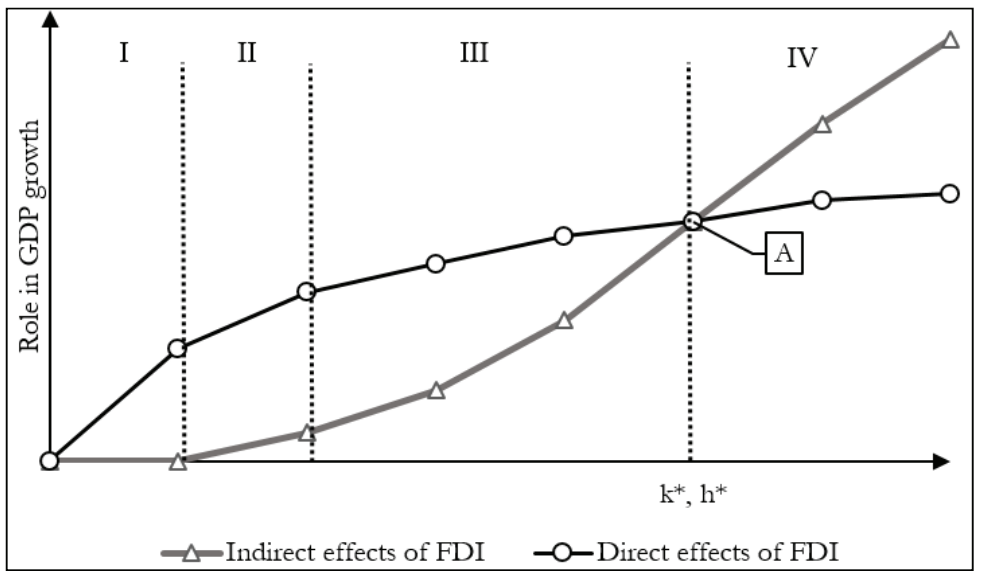

Note that the length of each particular stage is host-investor dependent and not necessarily as long as they are presented here.

Source: Author's own elaboration.

This leads to very interesting observations. Namely, the bigger the difference between $k^{*}$ and $k$ and $b^{*}$ and $h$ (when $k^{*}>k$ and $b^{*}>b$ ), the bigger the role of the direct effects of inward FDI and the smaller the impact of indirect effects. As the value of

16 For more thoughts on changes in the savings rate see e.g. [Romer, 2001]. 
$k$ and $h$ (the absorptive capacity) increase so does the (relative to direct) role of spillover effects of FDI as regards the level of output per unit of labor force of the host economy.

Based on the above discussion, it is possible to divide the absorptive capacity path (here introduced as the FDI Benefits Absorption Path, FBAP) into four distinctive stages (Figure 1). Stage I is a stage, in which the host economy has no absorptive capacity (hence, $\frac{\partial y^{F D I}}{\partial g_{F D I}}=0$ and $\frac{\partial y^{F D I}}{\partial h_{F D I}}=0$ ) and the only benefits of hosting FDI are direct ones $\left(\frac{\partial y^{F D I}}{\partial w_{F D I}}>0\right.$ and $\left.\frac{\partial y^{F D I}}{\partial i_{F D I}}>0\right)$. In Stage II, the value of direct benefits of FDI increases and at this point there is some absorptive capacity present (e.g. due to the buildup of $k$ ); hence, indirect benefits of FDI begin to play a role in the host's economic development $\left(\frac{\partial y^{F D I}}{\partial g_{F D I}}>0\right.$ and $\frac{\partial y^{F D I}}{\partial h_{F D I}}>0$ and $\left(\frac{\partial y^{F D I}}{\partial w_{F D I}}, \frac{\partial y^{F D I}}{\partial i_{F D I}}\right)>\left(\frac{\partial y^{F D I}}{\partial h_{F D I}}, \frac{\partial y^{F D I}}{\partial g_{F D I}}\right)$. However, there is still divergence between the sizes of the values of the studied effects. This changes in Stage III, which is characterized by the diminishing of the values of direct benefits, while the role of indirect effects of FDI becomes more prominent, i.e. there is a convergence of the two values with the prior $\left(\left(\frac{\partial y^{F D I}}{\partial h_{F D I}}, \frac{\partial y^{F D I}}{\partial g_{F D I}}\right) \rightarrow\left(\frac{\partial y^{F D I}}{\partial w_{F D I}} \frac{\partial y^{F D I}}{\partial i_{F D I}}\right)\right.$. Stage IV begins after reaching the point ' $\mathrm{A}$ ', which is the point on the absorptive capacity path where, from the perspective of impacting the growth of the host economy, the values of the direct and indirect benefits of FDI are equal $\left(\left(\frac{\partial y^{F D I}}{\partial w_{F D I}}, \frac{\partial y^{F D I}}{\partial i_{F D I}}\right)=\left(\frac{\partial y^{F D I}}{\partial h_{F D I}} \frac{\partial y^{F D I}}{\partial g_{F D I}}\right)\right.$. After this point, there is a divergence of the values of the benefits with the prominent role being played by the indirect benefits of FDI $\left(\left(\frac{\partial y^{F D I}}{\partial w_{F D I}}, \frac{\partial y^{F D I}}{\partial i_{F D I}}\right)<\left(\frac{\partial y^{F D I}}{\partial h_{F D I}}, \frac{\partial y^{F D I}}{\partial g_{F D I}}\right)\right.$.

This explains why the estimation of the effects of FDI on the host economy yields such heterogeneous results. For example, a negative or statistically insignificant ratio of indirect benefits in the first and partially in the second stage of FBAP should not be surprising. Therefore, the results of previous works should first be divided into those relating to the direct and those relating to the indirect benefits and then viewed through the prism of the stage on the FBAP, which the examined host currently occupies. Another important implication for future empirics on this subject is that the selection of subjects for panel studies should be based on their homogeneity in terms of their stage on the FBAP.

\section{Implications for the growth policy}

The presented concept of FBAP can also find its application in the development of the growth policy.

For economies located in the first stage, the main implication for the maximization of growth with the use of inward FDI is the need to focus on attracting low-technology FDI as these will most positively impact the host's growth. Attempts to attract high- 
and medium-technology FDI should not be implemented as the host economy does not yet have the absorptive capacity in order to obtain the benefits of FDI spillovers.

If the host is in the second stage, the policy of attracting low-technology FDI should continue and direct benefits of hosting FDI should be re-invested into the buildup of the host's absorptive capacity. Such investments should be gradually increasing as the host moves along the FBAP. At this point, any other than low-technology FDI are considered to be marginal.

Economies placed in the third stage of the FBAP should use their accumulating absorptive capacity to decrease their reliance on direct benefits (as their value for economic growth is decreasing). At the beginning of this stage, low-technology FDI should be crowded out by medium-technology FDI (host itself becomes a low-technology investor), while at the end of the third stage, medium-technology FDI should be forced out by high-technology FDI.

Lastly, in the fourth stage of the FBAP, the host's policy should give priority to attracting chiefly high-technology FDI with a goal of becoming a medium (and eventually high) technology investor. At this stage, the host's growth is chiefly innovation driven.

\section{Conclusion}

The motivation for this study was the vast degree of heterogeneity across the studies on the impact of FDI on the economic growth of the host economy.

The goals of this study were to (H1) show the degree of endogenization of FDI in the economic growth of the host and (H2) to show different paths of direct and indirect effects of FDI on the host. The aim of all of them was to explain the heterogeneity of results across the studies on the mentioned effects.

Firstly (H1), this article endogenizes FDI, by presenting the depth of its interaction with the economic growth of the host economy. This shows that the estimation of the impact of FDI on the host without the proper measurements and inclusion of the mentioned FDI-related variables may lead to incorrect results.

Secondly (H2), and chiefly, this article shows that the heterogeneity across the studies of the impact of FDI on the host economy may stem from their stage on the introduced here FDI Benefits Absorption Path (the first instrument to regard the topic of the impact of benefits of FDI in a manner it does) as it, e.g. explains why the measurement of the value of the indirect benefits for the hosts located in Stage I or in early Stage II may yield negative or statistically insignificant results. This highlights the notion of the interchanging order of importance between the direct and indirect effects of hosting FDI as the host economy procedes along FBAP. The study has also shown that an attempt to estimate the total impact of FDI on the host may yield spurious results.

Such findings may be also applied to the economic growth policy as various FDI (on a technology spectrum) should be attracted at various stages of the FBAP in order to maximize their impact on the economic growth of the host.

Further studies should focus on the topic of the determinants of absorptive capacity and the question of their hetero- or homogeneity across studied economies with a hypothesis of the prior. Next, further studies should focus on the determinants of the 
cut-off points between the four stages of the FBAP, which would lead to the study of the length of each of the mentioned stages. Another possible study might concentrate on how the FBAP would change if instead of (domestic-only) absorptive capacity measured as a function of $k$ and $h$, it would be expressed as a difference (of technology or productivity) between the host's and the home economies.

\section{References}

Aghion P., Howitt P., 1992, A Model of Growth through Creative Destruction, „Econometrica”, No. 60, doi:10.3386/w3223.

Ahmed K., Ghani T., Gairuzazmi M., Noorihsan M., Derus A.M., 2015, Does Inward FDI Crowd-out Domestic Investment? Evidence from Uganda, „Procedia - Social and Behavioral Sciences", No. 172, https://doi.org/10.1016/j.sbspro.2015.01.395.

Alfaro L., 2003, Foreign Direct Investment and Growth: Does the Sector Matter? „Semanic Scholar", https://pdfs.semanticscholar.org/7800/b094ee3c677a2b729345eeb0 5c696ed9a2e0.pdf?_ga $=2.255193096 .1432754311 .1519326826-126121812.1470$ 476307 (date of access: 14.06.2016).

Azam M., Ahmed A.M., 2015, Role of Human Capital and Foreign Direct Investment in Promoting Economic Growth, „International Journal of Social Economics”, No. 42, https://doi.org/10.1108/IJSE-05-2014-0092.

Blomström M., Kokko A., 2003, The Economics of Foreign Direct Investment Incentives, „National Bureau of Economic Research”, Working Paper, No. 9489.

Blomström M., Sjöholm F., 1999, Technology Transfer and Spillovers: Does Local Participation with Multinationals Matter?, „European Economic Review”, No. 43, https://doi.org/10.1016/S0014-2921(98)00104-4.

Borensztein E., De Gregorio J., Lee J-W., 1998, How Does Foreign Direct Investment Affect Economic Growth, ,Journal of International Economics”, No. 45, https://doi.org/ 10.1016/S0022-1996(97)00033-0.

Branstetter L., 2006, Is foreign direct investment a channel of knowledge spillovers? Evidence from Japan's FDI in the United States, ,Journal of International Economics", No. 68, https://doi.org/10.1016/j.jinteco.2005.06.006.

Burda M.C., Severgnini B., 2014, Solow Residuals Without Capital Stock, ,Journal of Development Economics", No. 109, https://doi.org/10.1016/j.jdeveco.2014.03.007.

Carkovic M.V., Levine R., 2002, Does Foreign Direct Investment Accelerate Economic Growth, Univeristy of Minnestora Department of Finance Working Paper, http://siteresources.worldbank.org/INTFR/Resources/fdi.pdf (date of access: 14.06.2016).

Damijan J.P., Rojec M., Majcen B., Knell M., 2013, Impact of Firm Heterogeneity on Direct and Spillover Effects of FDI: Micro-evidence from Ten Transition Countries, ,Journal of Comparative Economics", No. 41, https://doi.org/10.1016/j.jce.2012.12.001.

Damijan J.P., Kostevc C., 2011, Trade Liberalisation and Economic Geography in CEE Countries: the Role of FDI in the Adjustment Pattern of Regional Wages, „P Post Communist Economies", No. 23, http://dx.doi.org/10.1080/14631377.2011.570041. 
Fatima S.T., 2016, Productivity Spillovers from Foreign Direct Investment: Evidence from Turkish Micro-level Data, „The Journal of International Trade \& Economic Development", No. 25, http://dx.doi.org/10.1080/09638199.2015.1050057.

Farla K., De Crombrugghe D., Varspagen B., 2016, Institutions, Foreign Direct Investment, and Domestic Investment: Crowding Out or Crowding In?, „World Development”, No. 88, https://doi.org/10.1016/j.worlddev.2014.04.008.

Heyman F., Sjöholm F., Tingvall P.G., 2007, Is There Really a Foreign Ownership Wage Premium? Evidence from Matched Employer-Employee Data, ,Journal of International Economics", nr 73, https://doi.org/10.1016/j.jinteco.2007.04.003.

Iamsiraroj S., 2016, The Foreign Direct Investment-Economic Growth Nexus, „International Review of Economics and Finance", No. 42, https://doi.org/10.1016/j.iref.2015. 10.044.

Iamsiraroj S., Ulubaşoğlu M.A., 2015, Foreign Direct Investment and Economic Growth: A Real Relationship or Wishful Thinking?, „Economic Modelling”, No. 51, https://doi.org/10.1016/j.econmod.2015.08.009.

Javorcik B.S., 2015, Does FDI Bring Good Jobs to Host Countries?, „,World Bank Research Observer", No. 30.

Keller W., 2009, International Trade, Foreign Direct Investment, and Technology Spillovers, „National Bureau of Economic Research”, Working Paper 15442.

Kornecki L., 2008, Foreign Direct Investment and Macroeconomic Changers in CEE Integrating into the Global Market, „Investment and Management and Financial Innovations”, No. 5.

Kuskowski P., Sadowski J., Strojny M., 2010, 20 Years of American Investment in Poland, American Chamber of Commerce in Poland, KPMG Sp. z o.o.

Lipsey R.E., 2002, Home and Host Country Effects of FDI, „National Bureau of Economic Research", Working Paper 9293.

Liu W.S., Agbola F.W., Dzator J.A., 2016, The Impact of FDI Spillovers Effects on Total factor Productivity in the Chinese Electronic Industry: a Panel Data Analysis, ,Journal of the Asia Pacific Economy", nr 21, http://dx.doi.org/10.1080/13547860.2015. 1137473.

McGrattan E.R., 2011, Transition to FDI Openness: Reconciling Theory and Evidence, „National Bureau of Economic Research", Working Paper 16774.

Morrissey O., Udomkerdmongkol M., 2016, Response to Institutions, Foreign Direct Investment, and Domestic Investment: Crowding Out or Crowding In?, „World Development”, No. 88, https://doi.org/10.1016/j.worlddev.2016.08.001.

Morrissey O., Udomkerdmongkol M., 2012, Governance, Private Investment and Foreign Direct Investment in Developing Countries, ,,World Development”, No. 40, https:/ / doi.org/ 10.1016/j.worlddev.2011.07.004.

Munteanu A-C., 2016, Knowledge Spillovers of FDI, „Procedia Economics and Finance”, No. 32, https://doi.org/10.1016/S2212-5671(15)01573-7.

Nair-Reichert U., Weinhold D., 2001, Causality Test for Cross-Country Panels: New Look at FDI and Economic Growth in Developing Countries, ,Oxford Bulletin of Economics and Statistics", No. 63, DOI: 10.1111/1468-0084.00214. 
Nölke A., Vliegenthart A., 2009, Enlarging the Varieties of Capitalism: The Emergence of Dependent Market Economies in East Central Europe, „World Politics”, No. 61, DOI: http://www.jstor.org/stable/40263536.

Nunnenkamp P., 2002, To What Extent Can Foreign Direct Investment Help Achieve International Development Goals?, „Kiel Institute of World Economics”, Kiel Working Paper 1128.

Pilbeam K., Oboleviciute N., 2012, Does Foreign Direct Investment Crowd In or Crowd Out Domestic Investment? Evidence from the European Union, „The Journal of Economic Asymmetries", No. 9, https://doi.org/10.1016/j.jeca.2012.01.005.

Popescu G.H., 2014, FDI and Economic Growth in Central and Eastern Europe, „Sustainability", No. 6, DOI: 10.3390/su6118149.

Romer D., 2001, Advanced Macroeconomics, McGraw-Hill/Irwin, New York.

Romer P.M., 1990, Endogenous Technological Change, ,Journal of Political Economy”, No. 98.

Solow R.M., 1956, A contribution to the theory of economic growth, „The Quarterly Journal of Economics", No. 70, https://doi.org/10.2307/1884513.

Svedin D., Stage J., 2016, Impact of Foreign Direct Investment on Efficiency in Swedish Manufacturing, „Springerplus”, No. 5, DOI: 10.1186/s40064-016-2238-x.

Szkorupová Z., 2015, Relationship between Foreign Direct Investment and Domestic Investment in Selected Countries of Central and Eastern Europe, „Procedia Economics and Finance", No. 23, https://doi.org/10.1016/S2212-5671(15)00350-0.

Temiz D., Gökmen A., 2014, FDI Inflow as an International Business Operation by MNCs and Economic Growth: An Empirical Study on Turkey, „International Business Review", No. 23, https://doi.org/10.1016/j.ibusrev.2013.03.003.

Teixeira A.A.C., Queirós A.S.S., 2016, Economic Growth, Human Capital and Structural Change: A Dynamic Panel Data Analysis, „Research Policy”, No. 45, https://doi.org/ 10.1016/j.respol.2016.04.006.

Tomohara A., Takii S., 2011, Does Globalization Benefit Developing Countries? Effects of FDI on Local Wages, ,Journal of Policy Modeling”, No. 33, https://doi.org/ 10.1016/j.jpolmod.2010.12.010.

Tülüce N.S., Doğan İ., 2014, The Impact of Foreign Direct Investments on SMEs' Development, „Procedia - Social and Behavioral Sciences”, No. 150, https://doi.org/10.1016/ j.sbspro.2014.09.012.

Velde D.W. te, 2006, Foreign direct investment and development: An historical perspective, „World Economic and Social Survey for 2006”, Commissioned by UNCTAD.

Wang C.C., Wu A., 2016, Geographical FDI Knowledge Spillover and Innovation of Indigenous Firms in China, „International Business Review”, No. 25, https://doi.org/10.1016/ j.ibusrev.2015.12.004.

Zghidi N., Sghaier I.M., Abida Z., 2016, Does Economic Freedom Enhance the Impact of Foreign Direct Investment on Economic Growth in North African Countries? A Panel Data Analysis, African „Development Review”, No. 28, DOI: 10.1111/1467-8268.12167. 